\title{
Shari'ah and Ethical Issues in the Practice of the Modified Mudharabah Family Takaful Model in Malaysia
}

\author{
Sheila Nu Nu Htay and Syed Ahmed Salman
}

\begin{abstract}
Takaful is known as a Shari'ah compliant insurance in Muslim and non-Muslim countries. In this regard, Malaysia is a global leader in offering Islamic financial products and supports takaful. Due to the rapid growth of the takaful industry, the prevailing guidelines and regulations might not be adequate to capture the current needs of takaful operations. This has led to certain criticisms of the practice of the takaful industry from Shari'ah and ethical aspects. It is important to examine these issues because Shari'ah compliance and ethicality are the distinguishing factors that differentiate takaful from conventional insurance. If these issues are not resolved, participants and investors are set to lose confidence in the takaful industry. This paper focuses on the Shari'ah and ethical issues related to profit (surplus) sharing practice and the use of interest free loans in the modified mudarabah model used in family takaful products. The findings of this paper reveal the existence of unfavorable Shari'ah and ethical issues in the practice of takaful operations in Malaysia. As a result, the paper suggests that the regulators, Shari'ah advisors and industry players should revisit these issues in order to avoid reputational risk, Shari'ah compliant risk and early termination risk.
\end{abstract}

Index Terms-Family takaful, Malaysia and modified mudharabah model.

\section{INTRODUCTION}

Takaful is rapidly growing not only in Malaysia, Indonesia and Gulf countries but also in non-Muslim countries such as the United Kingdom, Thailand and Sri Lanka. Despite its continuous growth, there remains Shari'ah and ethical problems, challenges and issues that threaten the expansion and development of the takaful industry. In order to overcome these challenges and accomplish additional expansion and development, standing issues pertaining to the Shari'ah and ethics (adab) need to be resolved. Although Shari'ah scholars are still debating these issues, in the best interest of one's religion and honor, any form of unethical dealing or ambiguity in business transaction should be avoided and Muslims should avoid dubious and doubtful matters.

This paper is organized in four sections. The second section discusses the practice of the modified mudharabah model for family takaful products. The third section raises the Shar'iah and ethical issues and the last section concludes the paper.

Manuscript received June 19, 2013; revised August 21, 2013.

Sheila Htay is with International Islamic University Malaysia (e-mail: sheila@iium.edu.my).

\section{Practice OF THE Modified Mudharabah Model For FAMILY TAKAFUL IN MALAYSIA}

The earliest model for Family Takaful in Malaysia is the mudharabah model [1]. It is also known as "profit-sharing" or the "surplus-sharing" model [2]. Under this arrangement, a profit sharing contract is signed between the takaful operator as the entrepreneur (mudarib) who is entrusted to administer the takaful business and the participants as the capital providers (sahibul mal). Any profit is shared between the takaful operator and participants and the profit-sharing ratio is determined in the contract as agreed by both parties. Profit sharing in takaful is undertaken after all the related claims and expenses of takaful have been accounted for. In the event of loss or deficit of the takaful fund, the entire loss is borne by the participants. One distinctive feature in practice is that the shareholders shall provide free-interest loan (qard hassan) in order to overcome deficit in the participants' special account (PSA). This is to be repaid once the fund is in surplus. Moreover, the takaful operator is not allowed to charge any management fee from the contributions paid by the participants and all operational expenses shall be borne by the shareholders' fund.

There are two categories under mudharabah, namely the pure mudharabah model (see Fig. 1) or modified mudharabah model (see Fig. 2). The former allows profit-sharing on investment profit only between Takaful operators and the participants, whereas the latter allows profit-sharing on both investment profit and underwriting surplus between them. In practice, the takaful scheme in Malaysia normally uses pure mudharabah for the Participant's Account (PA) while the modified Mudharabah is used for the Participants' Special Account (PSA) [1].

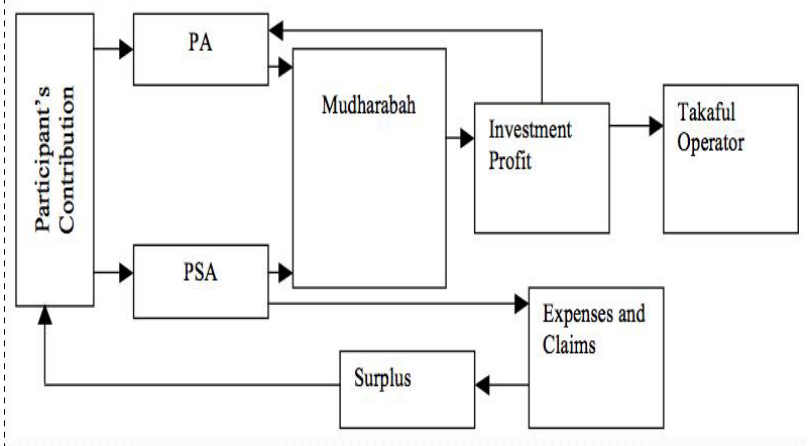

Fig. 1. Pure mudharabah model.

Under the pure mudharabah model, the participant's contribution is credited into PA for saving and investment purposes and PSA for donation. The PA belongs to the participant and PSA is owned by the takaful operator. Both 
PA and PSA are invested in Shar'iah compliant investments by the takaful operator. Any investment profit from these two accounts is shared according to a pre-agreed ratio. The PSA is used to pay claims and management fees, and allocate the reserve. Any net underwriting surplus is returned to the participants. Upon maturity or claims, the participants or beneficiaries are paid from the accumulated balance from PA together with the coverage amount from the PSA.

Under the modified mudharabah model, the treatment of PSA is similar with the pure mudharabah model. The only difference is that the modified mudharabah model allows the takaful operators to share the underwriting surplus as an incentive for the takaful operators.

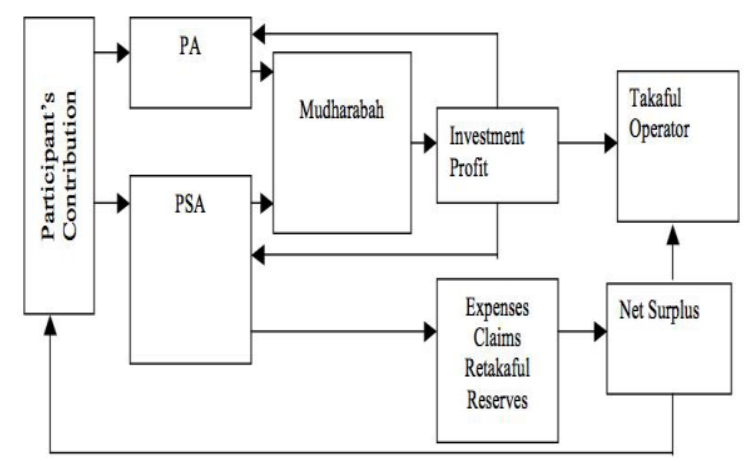

Fig. 2. Modified mudharabah model.

\section{Shariah AND ETHICAL ISSUES IN MODIFIED MUDHARABAH MODEL}

\section{A. Profit (Surplus) Sharing Issue in Modified Mudahrabah Model}

Shari'ah scholars differ in their opinion on whether the net underwriting surplus can be treated as mudharabah profit or otherwise. This is one of the major issues in the modified mudharabah model. As mentioned earlier, the main feature in modified mudharabah model is to share underwriting surplus between the takaful operator and participants. This approach has received a number of criticisms particularly by Middle Eastern scholars and Islamic jurisprudents. The main reason for adopting this practice is due to the low profitability and slow growth as well as less feasibility of the pure mudharabah model [1]. As far as the pure mudharabah is concerned, the only main source of income for takaful operators is the profits generated from the investment activities using the funds allocated in PA and PSA. Soualhi [3] stated that the justification given for the practice of sharing underwriting surplus in the modified mudharabah model is based on the grounds that such an arrangement would allow takaful operators to withstand competition with its conventional counterpart and avoid overpricing. He further justified that there is no explicit Shari'ah principle that prohibits such a practice. Indeed, surplus sharing can be seen as an incentive for the takaful operator for their hard work and relentless commitment in managing the takaful funds.

In answering this issue, the Shari'ah Advisory Council of Bank Negara Malaysia (SAC) has passed the resolution which allows the distribution of the surplus from the participants' risk fund between the participants and takaful operator. This decision is based on the fact that the takaful contract is generally formed on the concept of tabarru (donation) and ta awun (cooperative), as well as the mutual agreement between the contracting parties. The tabarru principle is the main underlying principle of the takaful product, while the mudharabah contract is applied in the management of Takaful operation. The SAC considered the distribution as a performance fee for the takaful operator. Moreover, the participants' consent to share the risk fund surplus with the takaful operator as the fund manager does not contradict with Shari'ah principles.

Nevertheless, the opponents of sharing underwriting surplus put forward their argument that the practice of treating net underwriting surplus as mudharabah profit is not in line with the definition of profit according to the original mudharabah contact. It contradicts the general mudharabah rules [1]. It is also claimed that sharing of the underwriting surplus is tantamount to making takaful into a commercial business venture instead of a contract that is based on brotherhood solidarity and mutual co-operation [4]. Generally, mudharabah profit is defined as a surplus over and above the general capital after deduction of costs and expenses. However, in this situation, there is usually no surplus over and above the original capital because of the reduction due to claims or other expenses. The remainder is only the net underwriting surplus, which is lower than the original mudharabah capital even after addition of any profit generated from the investment activities. In addition, the AAOIFI Standard on takaful does not allow the takaful operators to share underwriting surplus as they believe the underwriting surplus exclusively belongs to the participants.

Due to this endless debate, the majority of takaful operators in Malaysia have now opted for the wakalah model after applying the mudharabah model for more than two decades [3].

\section{B. Qard Hassan (Interest Free Loan)}

Another main feature of the modified mudharabah model is the interest free loan (qard hassan). This feature has also drawn some controversial issues. Under the modified mudharabah model, the shareholders are obliged to provide interest free loans to the participants in the event of any deficit in the PSA fund. This practice has been discussed and mentioned in the Shari'ah Resolutions in Islamic Finance issued by the Bank Negara Malaysia as one of the mechanisms to overcome deficit in the PSA fund. However, the terms and conditions of qard hassan in terms of repayment and timing of the drawdown are not certain and clear [5]. Onagun [6] mentioned that there is difficulty on how to maintain fairness among the different generations of participants because the new participants may be adversely affected by paying higher contribution or receive small or no underwriting surplus due to the need of making repayments of qard hassan. It must be noted that the setting of contribution levels must not result in a higher fee, otherwise this will defeat the purpose of qard hassan as a benevolent or interest free loan.

Recently, an academic study found that Muslim scholars do not agree with the issue of qard hassan adopted in the modified mudharabah model [7]. The research also found 
that takaful operators are choosing the models in order to maximize their self-interest, rather than the interest of the participants. Apart from that, one common issue in relation to qard hassan is the misinterpretation of its concept [8]. Since qard hassan is a benevolent loan, it means that under this original principle, the borrower cannot be forced to make repayment. In the event the borrower is unable to settle the loan, the lender must accept this transaction as a charitable act. In the context of takaful, this is the main reason why some shareholders are quite reluctant to offer qard hassan when there is deficit in the takaful fund.

\section{CONCLUSION}

This paper highlights the Shari'ah and ethical issues in the practice of modified mudharabah model for family takaful products in Malaysia. The paper opined that the modified mudharabah model is yet to prove that it is the best model for all affected parties. The unfavorable Shari'ah and ethical issues should be resolved as soon as possible and the regulators should improve the existing model or introduce or recommend a new model to reflect the concept of donation and mutual help.

\section{REFERENCES}

[1] E. R. A. E. Ali and H. S. P. Odierno, Essential Guide to Takaful (Islamic Insurance), CERT Kuala Lumpur, 2008.

[2] N. Yassin and J. Ramly, Takaful: A Study Guide, IBFIM Kuala Lumpur, 2011.

[3] S. Younes, "Shariah inspection in surplus distribution: Shariah views and their current implementation," ISRA Islamic Finance Seminar (IIFS), 2008

[4] M. F. Yusof, W. Z. I. W. Ismail, and A. K. M. Naaim, Fundamentals of Takaful, IBFIM Kuala Lumpur, 2011.

[5] J. Sohail, Islamic Insurance: Trends, Opportunities and the Future of Takaful, Euromoney Institutional Investment PLC, 2007.

[6] O. A. Ismail, "Solvency of takaful fund: a case of subordinated qard," in Proc. 2nd International Conf. on Business and Economics Research, 2011.

[7] H. N. N. Sheila and H. R. Zaharin, "Critical analysis on the choice of takaful (Islamic Insurance) operating models in Malaysia," World Journal of Social Sciences, vol. 2, no. 2, 2012.

[8] G. B. S. Atan, The Concept of Al-Qard Ul-Hassan, 2009.

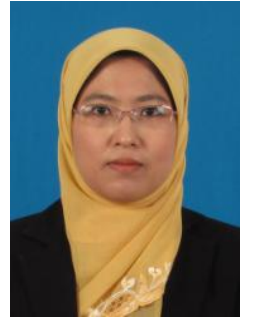

Sheila Nu Nu Htay was born in January 14, 1974 in Mandalay, Myanmar. She has completed her bachelor, master and $\mathrm{Ph} . \mathrm{D}$. in Accounting from the International Islamic University Malaysia in 2009. She is an assistant professor and Ph.D. programme Coordinator at the Institute of Islamic Banking and Finance, International Islamic University Malaysia (IIUM). Her area of expertise covers accounting for Islamic banks, Takaful and Re-takaful Companies and Islamic capital markets. She has written several books. Among them, "Accounting, Auditing and Governance for Takaful Operators" published by John Wiley and Sons pte. Ltd. in 2012 and "Financial Accounting and Reporting for Islamic banks" which will be published by IBFIM in September, 2013. She has published a number of articles, among them "Shariah Scholars' View Point on the Practice of Underwriting and Risk Rating for Family Takaful Model" and "Critical Analysis on the Choice of Takaful (Islamic Insurance) Operating Models in Malaysia."

Dr. Sheila is a financial and Shari'ah compliance advisor for Myint Myat Phu Zin Clinic (waqf, zakat and charity based clinic) in Myanmar, committee Member for Islamic Finance Education Cluster (EPP7), reviewer and member of editorial board (The Journal of Islamic Finance) and reviewer for conference papers and articles by World Business Institute Pty Ltd. Australia. She has received a number of awards such as best paper award, best lecturer award and best manager award and many more.

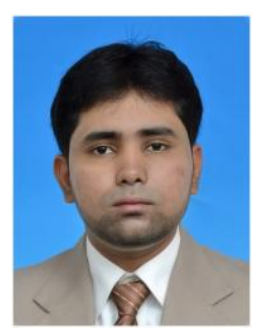

Syed Ahmed Salman was born on September 14, 1984 in Hyderabad, India. He has completed his bachelor degree in Shari'ah and jurisprudence from Darul-uloom Nadwatul Ulama Lucknow, India in 2008 and master of science in Islamic Banking and Finance from IIUM Institute of Islamic Banking and Finance, International Islamic University Malaysia in 2012. Currently he is a Ph.D. candidate at IIUM Institute of Islamic Banking and Finance. He is the vice president of Madarse Ashfaq- ul-uloom in Hyderbabd, India and assistant editor of the monthly magazine "Al Alai" in Hyderbad, India. He has presented several research papers at national and international conferences and have a number of articles published in peer-reviewed academic journals. His areas of expertise include Shari'ah Law, Islamic banking, corporate governance and Takaful. He has published a number of articles among them "Shariah Scholars' View Point on the Practice of Underwriting and Risk Rating for Family Takaful Model", "Prospects of Islamic Insurance in India", "Future of Islamic Insurance (Takaful) in India", and "Nomination and Hibah issues in Malaysian Takaful industry." 